\title{
Effect of the ratio of zinc amino acid complex to zinc sulfate on the performance of Holstein cows
}

\author{
A. Nayeri, ${ }^{\star}$ N. C. Upah, ${ }^{\star}$ E. Sucu, ${ }^{\star} †$ M. V. Sanz-Fernandez, ${ }^{\star}$ J. M. DeFrain,‡ P. J. Gorden,§ \\ and L. H. Baumgard*1 \\ *Department of Animal Science, lowa State University, Ames 50011 \\ †Department of Animal Science, Uludağ University, 16059 Bursa, Turkey \\ $\ddagger Z$ inpro Corporation, Eden Prairie, MN 55344 \\ §College of Veterinary Medicine, lowa State University, Ames 50011
}

\begin{abstract}
Multiparous $(\mathrm{n}=70)$ and primiparous $(\mathrm{n}=66)$ Holstein cows were balanced by 305 -d previous matureequivalent milk yield and parity and assigned to 1 of 3 dietary treatments to evaluate the ratio of zinc sulfate to zinc amino acid complex $(\mathrm{CZ})$ in pre- and postpartum Holstein cows fed diets containing $75 \mathrm{mg}$ of added zinc $/ \mathrm{kg}$. Treatments were (1) $75 \mathrm{mg}$ of supplemental zinc $/ \mathrm{kg}$ of dry matter (DM) provided entirely as zinc sulfate (0-CZ); (2) 0-CZ diet, except $33.3 \mathrm{mg}$ of zinc sulfate $/ \mathrm{kg}$ of DM in the prepartum and $15.5 \mathrm{mg}$ of zinc sulfate $/ \mathrm{kg}$ of DM in the postpartum diet were replaced by CZ from Availa-Zn (16-CZ; Zinpro Corp., Eden Prairie MN); and (3) 0-CZ diet, except $66.6 \mathrm{mg}$ of zinc sulfate $/ \mathrm{kg}$ of DM in the prepartum and $40.0 \mathrm{mg}$ of zinc sulfate $/ \mathrm{kg}$ of DM in the postpartum diet was replaced by Availa-Zn (40-CZ). Cows were housed at the Iowa State University Dairy Farm and were individually offered a total mixed ration containing dietary treatments beginning at $28 \pm 15 \mathrm{~d}$ before expected calving date until $250 \mathrm{~d}$ in milk. Relative to $0-\mathrm{CZ}$, multiparous cows (but not primiparous) fed CZ (16-CZ or 40-CZ) had increased (20\%) colostrum IgG concentrations. Prepartum DM intake (DMI) was decreased with CZ supplementation. Postpartum DMI was decreased in cows fed CZ, whereas milk yield (MY) was increased in the 40-CZ-fed cows relative to those fed both $0-\mathrm{CZ}$ and 16-CZ. Feed efficiency increased linearly when measured as MY/DMI, 3.5\% fat-corrected MY/DMI, and solids-corrected MY/DMI. Regardless of level, feeding CZ decreased services per conception. Feeding 16-CZ decreased milk fat concentration and feeding CZ linearly increased milk urea nitrogen concentration. In summary, supplementing zinc as a mixture of $\mathrm{CZ}$ and zinc sulfate, as opposed to supplementing only zinc sulfate, has beneficial effects on production parameters
\end{abstract}

Received September 30, 2013.

Accepted April 2, 2014.

${ }^{1}$ Corresponding author: baumgard@iastate.edu in dairy cows, with those benefits becoming more apparent as the ratio of $\mathrm{CZ}$ to zinc sulfate increases.

Key words: zinc, production efficiency, lactation, somatic cell

\section{INTRODUCTION}

Zinc is indispensable for normal animal growth and health (NRC, 2001). Zinc is essential to over 300 enzymes (Dibley, 2001), many of which affect the metabolism of carbohydrates, proteins, lipids, and nucleic acids (NRC, 2001). Interactions with other metal ions, particularly copper and iron, and the presence of dietary organic chelating agents are 2 major factors affecting the efficiency of dietary zinc absorption (NRC, 2001). Research has demonstrated that amino acid complexes of trace minerals improve mineral bioavailability (Wedekind et al., 1992; Paripatananont and Lovell, 1995) as well as mineral retention (Nockels et al., 1993). Spears (1989) concluded that zinc from zinc oxide and zinc methionine complex was absorbed to the same extent by lambs, but more zinc was retained from zinc methionine complex as a result of lower urinary excretion.

Improved dairy cattle nutrition and management has markedly increased milk yield (MY) during the past few decades. Enhanced milk synthesis results in a concomitant increase in nutrient demands. The recommended dietary zinc content for dairy cattle is between 18 and $73 \mathrm{mg} / \mathrm{kg}$ of DM, depending upon the cows' life cycle stage and DMI (NRC, 2001). The requirement for zinc can be substantial, especially at peak milk production (4 mg/kg of milk; NRC, 2001). The effects of dietary antagonists, environment, stress, mineral source, and level of supplementation are not accounted for within current NRC (2001) trace mineral recommendations.

Improved dairy cow performance has been observed in cattle fed supplemental zinc in excess of NRC (2001) recommendations. For example, Campbell and Miller (1998) observed reduced days to first estrus and a tendency for reduced days to first service in cows fed 74 $\mathrm{mg} / \mathrm{kg}$ of supplemental zinc [50:50 blend of zinc sulfate 
and zinc amino acid complex $(\mathbf{C Z})]$ during the last $6 \mathrm{wk}$ of gestation. Further, a 12-trial summary by Kellogg et al. (2004) indicated that feeding CZ (180 to $400 \mathrm{mg}$ of zinc/d) increased ECM yield and decreased milk SCC relative to inorganic zinc. The zinc-methionine complex was fed in addition to inorganic zinc in all but 3 of the aforementioned trials. Excluding the 3 trials where total diet zinc content was not reported and assuming that $30 \mathrm{mg}$ of total zinc/ $\mathrm{kg}$ was derived from feedstuffs, supplemental zinc content averaged $48 \mathrm{mg} / \mathrm{kg}$ of DM. The reduction in milk SCC reported by Kellogg et al. (2004) was augmented when zinc was fed at $\geq 360 \mathrm{mg} /$ head per day (7 of the 12 trials) from CZ. However, the responses observed were partially confounded by the level of supplemental zinc. In addition, the supplementation of zinc-methionine complex began during the dry period in only 3 of the 12 trials. Therefore, we hypothesized that increasing the ratio of $\mathrm{CZ}$ to zinc sulfate during both the dry and lactation period would improve the performance of Holstein cows fed the same amount of supplemental zinc.

\section{MATERIALS AND METHODS}

\section{Animals and Sampling}

Animal care and use was according to a protocol approved by the Iowa State University Institutional Animal Care and Use Committee (Ames). The experiment was conducted from November 2010 through March 2012 at the Iowa State University Dairy Research Farm. Multiparous $(\mathrm{n}=100)$ and primiparous $(\mathrm{n}=84)$ Holstein cows were balanced by 305-d previous matureequivalent MY (if multiparous) and parity and assigned to 1 of 3 dietary treatments beginning $28 \pm 15 \mathrm{~d}$ before expected calving date and through $250 \pm 6$ DIM. Cows were initially excluded from the data set or removed from the trial using the following events defined at the onset of the experiment: spent less than $14 \mathrm{~d}$ on prepartum diet $(\mathrm{n}=8)$, diagnosed as carrying twins $(\mathrm{n}=$ 5), off treatment for $\geq 10$ d (i.e., if they were sick; $n=$ $19)$, had $<4$ functional mammary gland quarters ( $\mathrm{n}=$ 3 ), or were not pregnant as originally reported, died ,or were injured $(\mathrm{n}=13)$. If a cow was removed from the experiment after 100 DIM, her data was included in the final data set up to the elimination date.

Formulated diets, analyzed nutrient composition, and chemical composition of forages are shown in Tables 1, 2, and 3, respectively. With the exception of zinc source, all other dietary ingredients were the same within the prepartum and postpartum TMR across treatments. Diets were formulated assuming that feedstuffs did not contribute $\mathrm{Zn}, \mathrm{Mn}, \mathrm{Cu}$, and $\mathrm{Co}$ and that only the treatment mixes supplied $\mathrm{Zn}, \mathrm{Mn}, \mathrm{Cu}$, and $\mathrm{Co}$. Diets were isonitrogenous, isoenergetic, and balanced using Spartan Dairy Ration Evaluator 2.0 software (Michigan State University, East Lansing), which uses NRC (2001) recommendations. Prepartum diets were formulated for a Holstein cow with the following characteristics: consuming $10.6 \mathrm{~kg}$ of DM/d, 29 mo of age, $590 \mathrm{~kg}$ of $\mathrm{BW}, 0.36 \mathrm{~kg}$ of growth/d, and $10 \mathrm{~d}$ before freshening. Lactation diets were formulated for a Holstein cow with the following characteristics: consuming $23.2 \mathrm{~kg}$ of $\mathrm{DM} / \mathrm{d}, 42 \mathrm{mo}$ of age, in second lactation, $590 \mathrm{~kg}$ of BW, $0.41 \mathrm{~kg}$ of growth/d, 120 DIM, and producing $40 \mathrm{~kg}$ of milk/d with $3.7 \%$ fat and $3.2 \%$ protein. Upon the conclusion of the experiment, the latest version of the Cornell Net Carbohydrate and Protein System (CNCPS v6.1; Cornell University, Ithaca, NY) was released, allowing for improvements in estimating dietary ME and MP supply. Therefore, diet ME and MP were estimated using Nutritional Dynamic System (industry-licensed platform of CNCPS v6.1; RUM\&N Sas, Emilia, Italy) based upon actual DMI and dietary chemical composition.

Based upon the previous work of Campbell and Miller (1998) and Kellogg et al. (2004), prepartum and postpartum diets were formulated to supply $75 \mathrm{mg}$ of supplemental zinc $/ \mathrm{kg}$ of DM. This is greater than the zinc requirement calculated using NRC (2001) for prepartum $(30 \mathrm{mg} / \mathrm{kg})$ and postpartum $(56 \mathrm{mg} / \mathrm{kg}$ of DM) using the animal inputs described above. All diets contained the same quantity of supplemental zinc and only the proportion of zinc source differed between treatments (zinc sulfate and CZ; Availa-Zn 100; Zinpro Corp., Eden Prairie, MN). The zinc in $\mathrm{CZ}$ was bound to an amino acid in a ratio of 1 atom of metal bound to a single, unspecified amino acid. Treatments were (1) $75 \mathrm{mg}$ of supplemental zinc/ $\mathrm{kg}$ of DM, provided entirely as zinc sulfate (0-CZ); (2) 0 -CZ diet, except 33.3 $\mathrm{mg}$ of zinc sulfate $/ \mathrm{kg}$ of DM in the prepartum and 15.5 $\mathrm{mg}$ of zinc sulfate $/ \mathrm{kg}$ of DM in the postpartum diet was replaced by CZ from Availa-Zn (16-CZ); and (3) 0-CZ diet, except $66.6 \mathrm{mg}$ of zinc sulfate $/ \mathrm{kg}$ of $\mathrm{DM}$ in the prepartum and $40.0 \mathrm{mg}$ of zinc sulfate/ $\mathrm{kg}$ of DM in the postpartum diet was replaced by Availa-Zn (40-CZ). The source and level of all other trace minerals were similar across treatments. Our highest CZ treatment in the prepartum phase (66.6 $\mathrm{mg}$ of $\mathrm{CZ} / \mathrm{kg}$ on a DM basis) was designed to double the $\mathrm{CZ}$ dose $(400 \mathrm{mg} / \mathrm{d})$ used by Campbell and Miller (1998), whereas the highest CZ dose postpartum (40 $\mathrm{mg}$ of $\mathrm{CZ} / \mathrm{kg}$ on a DM basis) was formulated to double the largest CZ fed $(400 \mathrm{mg} / \mathrm{d})$ in the summary report by Kellogg et al. (2004). For simplicity, the treatment identifications noted in further sections (0-CZ, 16-CZ, and 40-CZ) are associated with 
Table 1. Ingredient composition of $\operatorname{diets}^{1}$

\begin{tabular}{lcc}
\hline Ingredient, \% of DM & $\begin{array}{c}\text { Prepartum } \\
\text { diet }\end{array}$ & $\begin{array}{c}\text { Postpartum } \\
\text { diet }\end{array}$ \\
\hline Alfalfa hay & 18.3 & 8.2 \\
Oat straw & 27.1 & - \\
Corn silage & 38.4 & 47.3 \\
Corn grain (ground) & - & 1.7 \\
Whole cottonseed & - & 9.0 \\
Soybean meal (48\%) & 16.2 & 6.1 \\
Close-up grain mix $^{2}$ & - & - \\
Lactation grain mix $^{3}$ & & 27.7 \\
\hline
\end{tabular}

${ }^{1}$ The prepartum diet was fed for approximately $28 \mathrm{~d}$ before calving. The postpartum ration was fed from 1 to 250 DIM.

${ }^{2}$ Consisted of $44.7 \%$ soybean meal; $29.9 \%$ ground corn; $7.5 \%$ blood meal; $4.5 \%$ magnesium sulfate; $3.0 \%$ XP Yeast (Diamond V Mills Inc., Cedar Rapids, IA); $3.0 \%$ ammonia chloride; $3.0 \%$ limestone; $1.5 \%$ salt; $2.9 \%$ premix [ $54.3 \%$ vitamin E 20,000, 20.4\% vitamin ADE, $10.2 \%$ selenium $0.06 \%, 4.6 \%$ Availa-Mn 80 (Zinpro Corp., Eden Prairie, MN), $2.5 \% \mathrm{MnSO}_{4}, 2.4 \%$ Rumensin 90 (Elanco Animal Health, Greenfield, IN), $2.3 \%$ Availa-Cu 100 (Zinpro Corp.), $1.7 \%$ colorant (Phibro Animal Health Corp., Teaneck, NJ), 0.88\% Copro 25 (Zinpro Corp.), $0.51 \%$ ethylenediamine dihydroiodide (EDDI), and $\left.0.29 \% \mathrm{CuSO}_{4}\right]$; and $0.125,0.068$, or $0.014 \% \mathrm{ZnSO}_{4}$ and $0,0.193$, or $0.386 \%$ Availa-Zn 100 (Zinpro Corp.; 0-CZ, 16-CZ, or 40-CZ, respectively, where $\mathrm{CZ}=$ zinc amino acid complex). Equal amounts of corn and soybean meal were substituted to account for differences in zinc concentration between Availa- $\mathrm{Zn}$ and $\mathrm{ZnSO}_{4}$.

${ }^{3}$ Consisted of $32.6 \%$ ground corn; $32.5 \%$ soyhulls; $18.6 \%$ Amino-plus (Ag Processing Inc., Omaha, NE); $4.2 \%$ fish meal, menhaden; $2.6 \%$ limestone; $2.1 \%$ animal fat; $1.9 \%$ urea; $1.9 \%$ magnesium sulfate; $1.7 \%$ sodium bicarbonate; $1.3 \%$ salt; $0.65 \%$ monocalcium phosphate and $0.94 \%$ lactation premix $(30.1 \%$ vitamin $\mathrm{ADE}$ mix, $27.9 \%$ vitamin E $20,000,18.3 \%$ selenium $0.06 \%, 5.8 \% \mathrm{MnSO}_{4}, 5.3 \%$ colorant, $3.8 \%$ Availa-Mn 80, 3.4\% Rumensin 90, 1.9\% Availa-Cu 100, 1.5\% $\mathrm{CuSO}_{4}$, $1.5 \%$ Copro 25, and 0.43\% EDDI); and 0.07, 0.06, or $0.03 \% \mathrm{ZnSO}_{4}$ and $0,0.05$, or $0.13 \%$ Availa-Zn 100 (0-CZ, 16-CZ, or 40-CZ, respectively). Soyhulls were substituted to account for differences in zinc concentration between Availa- $\mathrm{Zn}$ and $\mathrm{ZnSO}_{4}$.

the level of $\mathrm{CZ}$ fed in the postpartum phase only, as this phase represented the majority of the time period cows were fed their respective treatments.

Drinking water was sampled $1 \mathrm{wk}$ before trial start date (prepartum and postpartum supply) and 1 mo before trial completion (postpartum supply only) to test for trace mineral content and hardness (Table 4). Water samples were obtained after allowing the tap to run for 4 continuous minutes. After the sample was obtained, the bottle was sealed and stored at $4{ }^{\circ} \mathrm{C}$ and then shipped to the laboratory within $24 \mathrm{~h}$ for analysis. Dietary ingredients were sampled weekly and composited monthly (prepartum and postpartum).

Cows were housed on a wheat straw-bedded pack during the prepartum phase of the experiment. Beginning $28 \mathrm{~d}$ before expected calving, cows were weighed and body condition was scored (Wildman et al., 1982) by 2 trained individuals (scores averaged) every other week. In an attempt to improve the accuracy of BW parameters, individual cow daily BW was estimated by taking the difference between actual BW values divided by the
Table 2. Nutrient composition of forage ingredients (3 and 15 composites for the prepartum and postpartum diets, respectively) and SD listed in parentheses

\begin{tabular}{lccr}
\hline Item, & & & \\
DM basis & Corn silage & Alfalfa hay & Oat straw \\
\hline DM, \% & $34.4(4.42)$ & $86.2(2.98)$ & $86.3(2.55)$ \\
CP, \% & $7.0(0.93)$ & $18.5(0.97)$ & $3.0(1.57)$ \\
ADF, \% & $26.6(2.12)$ & $37.6(3.03)$ & $60.1(1.84)$ \\
aNDF, $\%$ & $42.8(3.17)$ & $47.9(3.79)$ & $83.9(1.24)$ \\
NFC, \% & $43.2(4.33)$ & $23.3(3.27)$ & $1.2(1.34)$ \\
Starch, \% & $31.5(4.17)$ & & \\
Sugar, \% & $2.5(1.34)$ & $5.8(1.16)$ & $3.2(0.45)$ \\
Lignin, \% & $3.2(0.35)$ & $8.4(0.71)$ & $11.5(0.60)$ \\
Fat, \% & $3.3(0.26)$ & $1.6(0.21)$ & $1.3(0.23)$ \\
Ash, \% & $3.9(0.94)$ & $9.2(0.67)$ & $10.2(1.59)$ \\
Ca, \% & $0.27(0.06)$ & $1.21(0.15)$ & $0.18(0.09)$ \\
P, \% & $0.24(0.04)$ & $0.30(0.04)$ & $0.09(0.06)$ \\
$\mathrm{Mg}, \%$ & $0.17(0.04)$ & $0.25(0.05)$ & $0.07(0.01)$ \\
$\mathrm{K}, \%$ & $0.94(0.17)$ & $2.03(0.32)$ & $2.28(0.65)$ \\
$\mathrm{Na}, \%$ & $0.01(0.01)$ & $0.06(0.02)$ & $0.33(0.18)$ \\
$\mathrm{Cl}, \%$ & $0.19(0.10)$ & $0.30(0.08)$ & $0.89(0.38)$ \\
$\mathrm{S}, \%$ & $0.10(0.01)$ & $0.21(0.04)$ & $0.08(0.02)$ \\
$\mathrm{Zn}, \mathrm{mg} / \mathrm{kg}$ & $29.9(4.19)$ & $30.1(3.95)$ & $16.9(7.36)$ \\
$\mathrm{Mn}, \mathrm{mg} / \mathrm{kg}$ & $19(2.70)$ & $32.4(9.55)$ & $17.9(6.01)$ \\
$\mathrm{Cu}, \mathrm{mg} / \mathrm{kg}$ & $8.3(3.17)$ & $10.1(1.77)$ & $4.1(1.13)$ \\
$\mathrm{Fe}, \mathrm{mg} / \mathrm{kg}$ & $121.7(88.50)$ & $192.6(49.27)$ & $63.9(28.19)$ \\
$\mathrm{Mo}, \mathrm{mg} / \mathrm{kg}$ & $0.65(0.34)$ & $1.02(0.55)$ & $0.48(0.50)$ \\
\hline
\end{tabular}

${ }^{1}$ Amylase-treated NDF.

number of days between days cows were weighed. Cows were individually fed ad libitum using the Calan Broadbent feeding system (American Calan Inc., Northwood, $\mathrm{NH})$. Feed was delivered twice daily to lactating cows (0800 and $1700 \mathrm{~h}$ ) and once daily to prepartum cows $(1100 \mathrm{~h})$. Orts were measured, recorded, and discarded daily $1 \mathrm{~h}$ before the morning feed delivery and amounts fed were adjusted to ensure $10 \%$ feed refusal.

Immediately postcalving, calves were weighed and removed from the dam to prevent nursing and cows were moved to a maternity barn, milked, and a colostrum sample was collected. Colostrum samples were frozen at $-20^{\circ} \mathrm{C}$ and retained until all samples had been collected. Following the initial milking, cows were moved into a preparation pen in the lactation barn for a minimum of 2 milkings. After passing a California mastitis test, cows were moved into the experimental pen and trained to an appropriate Calan gate and milked twice daily at 0700 and $1600 \mathrm{~h}$ for the reminder of the experiment. Milk samples for composition analyses were obtained weekly at the morning milking from each cow beginning at 7 and ending at $245 \pm 3$ DIM. The sample was stored at $4^{\circ} \mathrm{C}$ with a preservative (bronopol tablet; D \& F Control Systems Inc., San Ramon, CA) until analysis by Dairy Lab Services Inc. (Dubuque, IA). Blood samples and rectal temperatures were obtained from all cows on d $-21,-7,3,7,10,14,21,28$, and 56 \pm 1 DIM relative to calving. Blood samples were collected via coccygeal venipuncture using sodium heparin tubes (BD Vacutainer 366480; BD, Franklin Lakes, 
Table 3. Nutrient composition of prepartum and postpartum diets

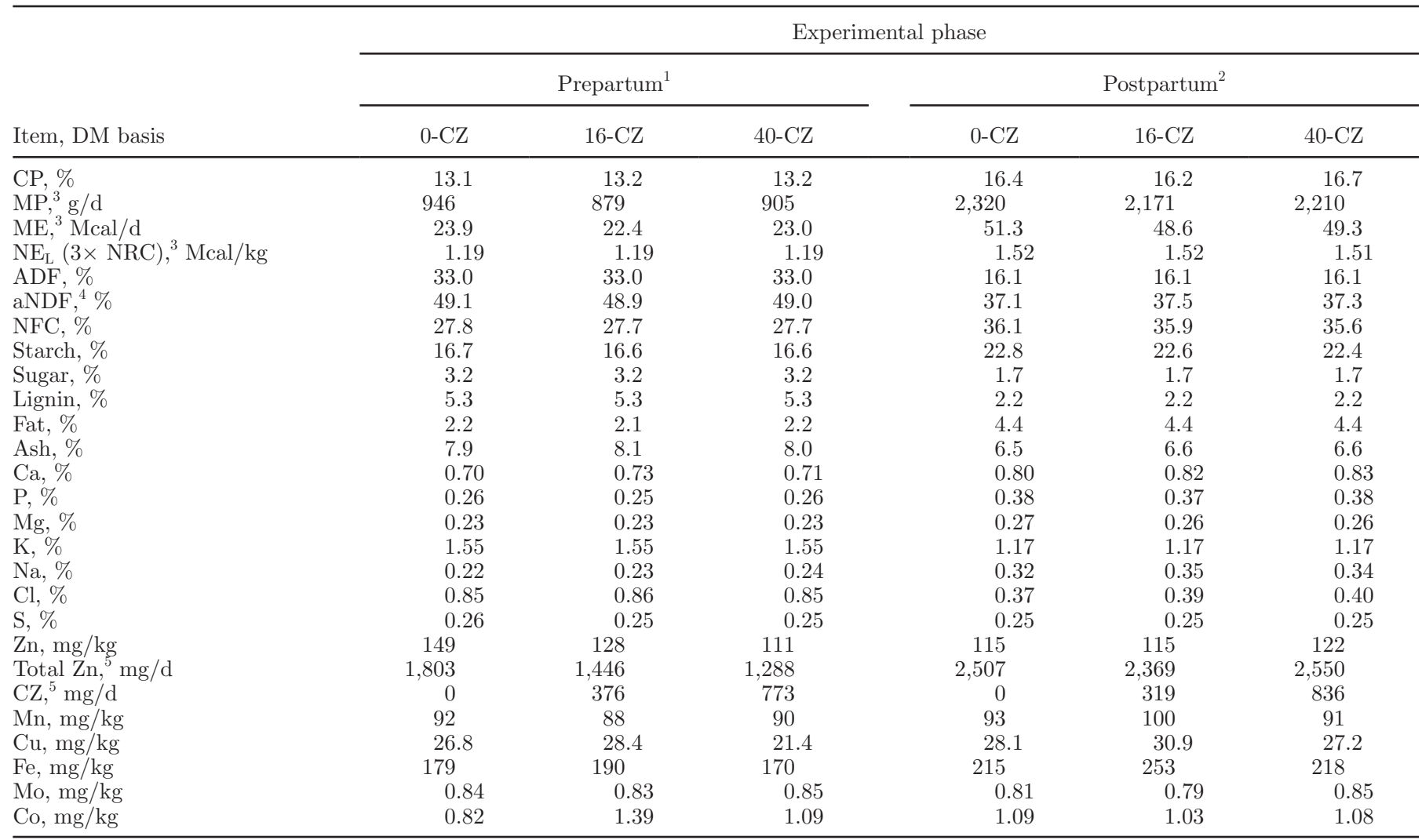

${ }^{1}$ Treatments were $\mathrm{ZnSO}_{4}$ (0-CZ, where $\mathrm{CZ}=$ zinc amino acid complex), $33.3 \mathrm{mg}$ of $\mathrm{CZ} / \mathrm{kg}$ of DM (16-CZ), and $66.6 \mathrm{mg}$ of CZ/kg of DM (40$\mathrm{CZ}$; 0 - CZ in the prepartum diet supplied $41.5 \mathrm{mg}$ of $\mathrm{Mn} / \mathrm{kg}$ from $\mathrm{MnSO}_{4} ; 18.5 \mathrm{mg}$ of $\mathrm{Mn} / \mathrm{kg}$ from Availa-Mn manganese amino acid complex (Zinpro Corp., Eden Prairie, MN); $3.4 \mathrm{mg}$ of $\mathrm{Cu} / \mathrm{kg}$ from $\mathrm{CuSO}_{4} ; 11.6 \mathrm{mg}$ of $\mathrm{Cu} / \mathrm{kg}$ from Availa-Cu copper amino acid complex (Zinpro Corp.); $1.11 \mathrm{mg}$ of $\mathrm{Co} / \mathrm{kg}$ from Copro cobalt glucoheptonate (Zinpro Corp.); 16 Availa-Zn, $33 \mathrm{mg} / \mathrm{kg}$ from Availa-Zn $+42 \mathrm{mg} / \mathrm{kg}$ from ZnSO Availa-Zn (Zinpro Corp.), $67 \mathrm{mg} / \mathrm{kg}$ from Availa- $\mathrm{Zn}+8.4 \mathrm{mg}$ of $\mathrm{Zn} / \mathrm{kg}$ from $\mathrm{ZnSO}_{4}$. Calculated vitamin levels were $11.1 \mathrm{kIU}$ of vitamin A/kg, $3.35 \mathrm{kIU}$ of vitamin $\mathrm{D} / \mathrm{kg}$, and $212.34 \mathrm{IU}$ of vitamin $\mathrm{E} / \mathrm{kg}$.

${ }^{2}$ Treatments were $\mathrm{ZnSO}_{4}$ (0-CZ), $15.5 \mathrm{mg}$ of $\mathrm{CZ} / \mathrm{kg}$ of DM (16-CZ), and $40.0 \mathrm{mg}$ of CZ $/ \mathrm{kg}$ of DM (40-CZ); 0-CZ in the postpartum diet supplied $51.4 \mathrm{mg}$ of $\mathrm{Mn} / \mathrm{kg}$ from $\mathrm{MnSO}_{4} ; 8.6 \mathrm{mg}$ of $\mathrm{Mn} / \mathrm{kg}$ from Availa-Mn manganese amino acid complex; $9.6 \mathrm{mg} \mathrm{of} \mathrm{Cu} / \mathrm{kg}$ from CuSO $4 ; 5.4 \mathrm{mg}$ of Cu/ $\mathrm{kg}$ from Availa-Cu copper amino acid complex; $1.08 \mathrm{mg}$ of $\mathrm{Co} / \mathrm{kg}$ from Copro cobalt glucoheptonate; 16 Availa-Zn, $16 \mathrm{mg} / \mathrm{kg}$ from Availa-Zn + $60 \mathrm{mg}$ of $\mathrm{Zn} / \mathrm{kg}$ from $\mathrm{ZnSO}_{4}$; and 40 Availa-Zn, $40 \mathrm{mg} / \mathrm{kg}$ from Availa-Zn $+35 \mathrm{mg}$ of $\mathrm{Zn} / \mathrm{kg}$ from $\mathrm{ZnSO}_{4}$. Calculated vitamin levels were 9.12 $\mathrm{kIU}$ of vitamin $\mathrm{A} / \mathrm{kg}, 2.76 \mathrm{kIU}$ of vitamin $\mathrm{D} / \mathrm{kg}$, and $25.4 \mathrm{IU}$ of vitamin $\mathrm{E} / \mathrm{kg}$.

${ }^{3}$ Estimated according to NRC (2001) at actual intakes using Nutritional Dynamic System (v3.8.6.01; RUM\&N Sas, Emilia, Italy), which uses the industry-licensed platform of the Cornell Net Carbohydrate and Protein System (CNCPS) 6.1 (Cornell University, Ithaca, NY) model.

${ }^{4}$ Amylase-treated NDF.

${ }^{5}$ Calculated using analyzed diet Zn content and average feed intake during the experiment.

NJ). Blood samples from lactating cows were obtained within $1 \mathrm{~h}$ after the morning feeding and just before feeding from prefresh cows. Samples were kept on ice until centrifuged at $1,300 \times g$ for 15 min at $4^{\circ} \mathrm{C}$, and plasma was split into 2 aliquots and frozen at $-20^{\circ} \mathrm{C}$ until analysis.

\section{Reproductive Management}

All cows were bred via AI, using a combination of visual estrus detection, activity monitors, and timed AI (TAI) for determination of proper timing for AI. All cows received 2 injections of $25 \mathrm{mg}$ of $\mathrm{PGF}_{2 \alpha}$ (Lutalyse;
Zoetis Animal Health, Madison, NJ) on Mondays if they were between 33 and 39 DIM and again between 47 and 53 DIM. Breeding technicians monitored cows daily for estrus at approximately $0800 \mathrm{~h}$ and inseminated cows at the time estrus if the cow was beyond the voluntary waiting period of 50 DIM. Cows that did not receive their first $\mathrm{AI}$ within $14 \mathrm{~d}$ of the second $\mathrm{PGF}_{2 \alpha}$ injection were introduced into a TAI program by administering $100 \mu \mathrm{g}$ of GnRH (Cystorelin; Merial Ltd., Duluth, GA) between 61 and 67 DIM. Seven days later, $25 \mathrm{mg}$ of $\mathrm{PGF}_{2 \alpha}$ was administered and a second 100 $\mu \mathrm{g} \mathrm{GnRH}$ injection was administered $56 \mathrm{~h}$ later. Cows were inseminated via TAI $16 \mathrm{~h}$ later to ensure that 
Table 4. Chemical composition and nutrient content of drinking water

\begin{tabular}{lccc}
\hline Drinking water & Prepartum & $\begin{array}{c}\text { Postpartum } \\
\text { (initial) }\end{array}$ & $\begin{array}{c}\text { Postpartum } \\
\text { (final) }\end{array}$ \\
\hline $\mathrm{pH}$ & 7.71 & 8.70 & 8.48 \\
Composition, mg/kg & & & \\
Nitrite & 5.21 & 5.08 & 1.07 \\
$\mathrm{Ca}$ & 38.04 & 34.90 & 37.71 \\
$\mathrm{Mg}$ & 18.54 & 18.19 & 24.23 \\
$\mathrm{P}$ & 1.64 & 0.25 & 0.08 \\
$\mathrm{~K}$ & 2.97 & 2.39 & 3.15 \\
$\mathrm{Cu}$ & 0.02 & $<0.01$ & 0.01 \\
$\mathrm{Fe}$ & 0.06 & 0.03 & 0.04 \\
$\mathrm{Zn}$ & 0.14 & 0.02 & 0.04 \\
$\mathrm{Na}$ & 12.19 & 11.73 & 30.55 \\
$\mathrm{Mn}$ & 0.01 & $<0.01$ & 0.01 \\
$\mathrm{Cl}$ & 33 & 27 & 47 \\
$\mathrm{Sulfates}$ & 57.42 & 56.79 & 110.46 \\
Total dissolved solids & 260 & 255 & 335 \\
Hardness, mg/kg & 171 & 162 & 194 \\
\hline
\end{tabular}

all cows received at least 1 insemination by 77 DIM. Any cow that exhibited estrus during the TAI program was removed from the TAI program and inseminated. Following insemination, cows were monitored for estrus daily and inseminated if estrus was detected. All cows that did not exhibit a subsequent estrus were enrolled in a resynchronization program 32 to $38 \mathrm{~d}$ after AI. Detection of pregnancy status was first performed by palpation per rectum 39 to $45 \mathrm{~d}$ after AI. Cows that were determined to be nonpregnant received $25 \mathrm{mg}$ of $\mathrm{PGF}_{2 \alpha}$ and a 100- $\mu \mathrm{g}$ GnRH injection $56 \mathrm{~h}$ later, and then underwent TAI $16 \mathrm{~h}$ later. Cows remained in this program until they were diagnosed pregnant. Confirmation of pregnancy status occurred via palpation per rectum at 70 to $76 \mathrm{~d}$ pregnant.

\section{Laboratory Analyses}

Drinking water was analyzed (Table 4) by Dairyland Laboratories Inc. (Acadia, WI) according to Eaton et al. (1995), using an inductively coupled plasma spectrometer (PerkinElmer 5300 DV OES; PerkinElmer Inc., Waltham, MA). Dietary ingredients were analyzed by wet chemistry methods (Dairyland Laboratories Inc.). Samples were dried at $55^{\circ} \mathrm{C}$ in a forced-air oven and allowed to air equilibrate before being ground to pass a 1-mm screen (Brinkmann ultracentrifuge mill; Brinkmann Instruments Co., Westbury, NY) and analyzed for CP using a Leco-628 combustion analyzer (Leco Corp., St. Joseph, MI), ether extract (AOAC International, 2005; method 920.39), and lignin (AOAC International, 1996; method 973.18). Starch was measured as dextrose after treating samples with glucoamylase using a YSI 2700 SELECT Biochemistry Analyzer (Application Note no. 319; YSI Inc., Yellow Springs, OH). Amylasetreated NDF concentration was determined according to
AOAC International (2005; method 2002.04) and ADF was measured according to AOAC International (1996; method 973.18). Minerals were quantified according to AOAC International (1996; method 985.01), using an inductively coupled plasma spectrometer (PerkinElmer 5300 DV OES; PerkinElmer Inc.). Analyses obtained from individual ingredients were used to rebuild the TMR and report the actual dietary nutrient composition found in Table 3.

Colostrum IgG content was determined by Global Beta Health (Ames, IA). Before the assay, samples were diluted 1:1,000 in assay buffer. Colostrum IgG concentration was determined using a radial immunodiffusion assay (Triple J Farms, Bellingham, WA). Milk composition was determined using (Dairy Lab Services Inc.) an AOAC International-compliant Fourier-transform infrared spectrophotometer (MilkoScan FT+; Foss Electric A/S, Hillerød, Denmark) and SCC was analyzed by a flow cytometer (Fossomatic FC; Foss Electric A/S).

Plasma NEFA, BHBA, and glucose concentrations were determined enzymatically using commercially available kits validated for use in our laboratory [NEFA C kit (Wako Chemicals USA Inc., Richmond, VA); BHBA (Pointe Scientific Inc., Canton, MI); Autokit Glucose C2 (Wako Chemicals USA Inc.)]. These procedures were scaled down and conducted in 96-well microplates (Rainin Instrument LLC, Oakland, CA) and read using a microplate photometer (SpectraMax Plus; Molecular Devices LLC, Silicon Valley, CA). The inter- and intraassay coefficients of variation for the BHBA, NEFA, and glucose assay were 10.6 and 5.8, 10.8 and $6.4,10.0$ and $2.6 \%$, respectively.

\section{Calculations and Statistical Analyses}

The final data set contained multiparous $(\mathrm{n}=70)$ and primiparous $(\mathrm{n}=66)$ cows and 53,43 , and 40 cows within the $0-\mathrm{CZ}, 16-\mathrm{CZ}$, and $40-\mathrm{CZ}$ treatments, respectively. All MY and DMI data were condensed to weekly means before analysis. Milk composition values were assigned to $3 \mathrm{~d}$ before and after theoretical sample day, except the sample obtained at d 7, which was assigned from d 1 to 10. Fat-corrected milk and SCM were calculated as described by Tyrrell and Reid (1965), using the following equations: $3.5 \% \mathrm{FCM}=[0.432 \times$ milk yield $(\mathrm{kg})]+[16.23 \times$ milk fat yield $(\mathrm{kg})] ; \mathrm{SCM}=(12.24$ $\times$ milk fat yield $)+(7.1 \times$ milk protein yield $)+(6.35$ $\times$ milk lactose yield $)-(0.0345 \times$ milk yield $)$. Feed efficiency was calculated as MY/DMI, FCM/DMI, and $\mathrm{SCM} / \mathrm{DMI}$.

Daily measurements were converted to weekly averages for analysis. Any week with less than 4 daily values per animal was removed from the data set and 
was considered a missing data point. Milk yield, 3.5\% FCM, 4.0\% SCM, milk components, DMI, and feed efficiency were analyzed by repeated measures, using PROC MIXED (Littell et al., 1996) of SAS (SAS Institute, 2005), with an autoregressive covariance structure and week as the repeated effect. Mean separations were analyzed with the PDIFF statement in SAS. Cows were blocked by season in which they calved [(1) January-March, (2) April-June, (3) July-September, and (4) October-December]. The model contained block, week, treatment, parity (lactation $=1$ vs. lactation $>1$ ), and all 2-way interactions, and cow was used as the random effect. Single measurements (i.e., colostrum IgG concentration; services per conception, and DIM at conception, among others) were analyzed using PROC ANOVA of SAS (SAS Institute, 2005). Rectal temperature, plasma NEFA, BHBA, and glucose were analyzed by repeated measures using PROC MIXED of SAS, with an autoregressive covariance structure and day as the repeated effect. The model contained block, day, treatment, parity, and all 2-way possible interactions, and cow as the random effect. Preplanned contrasts were used to determine the effect of $\mathrm{CZ}$ (0CZ vs. 16- and 40-CZ, noted as zinc source effect), whereas orthogonal contrast statements were used to determine linear and quadratic effects of $\mathrm{CZ}$ dose. Percentage pregnant at 150 DIM was analyzed using PROC LIFETEST of SAS. Least squares means and standard errors of the mean are reported and differences were considered significant at $P<0.05$ and a trend at $P<0.10$.

\section{RESULTS}

Complexed zinc decreased prepartum and postpartum DMI by 5.7 and $5.0 \%$, respectively (source effect: $P<0.05$; Table 5). A treatment by parity interaction $(P<0.05)$ in postpartum DMI was detected, as multiparous cows fed 16-CZ and 40-CZ had decreased DMI (7.5\%, on average) compared with multiparous cows fed $0-\mathrm{CZ}$, but no effect of treatment in primiparous cows was detected.

Colostrum IgG concentration tended to increase linearly with increasing $\mathrm{CZ}$ content $(P=0.10$; Table 5$)$. A

Table 5. Effects of treatment on feed intake, colostrum IgG concentration, milk yield, and milk composition ${ }^{1}$

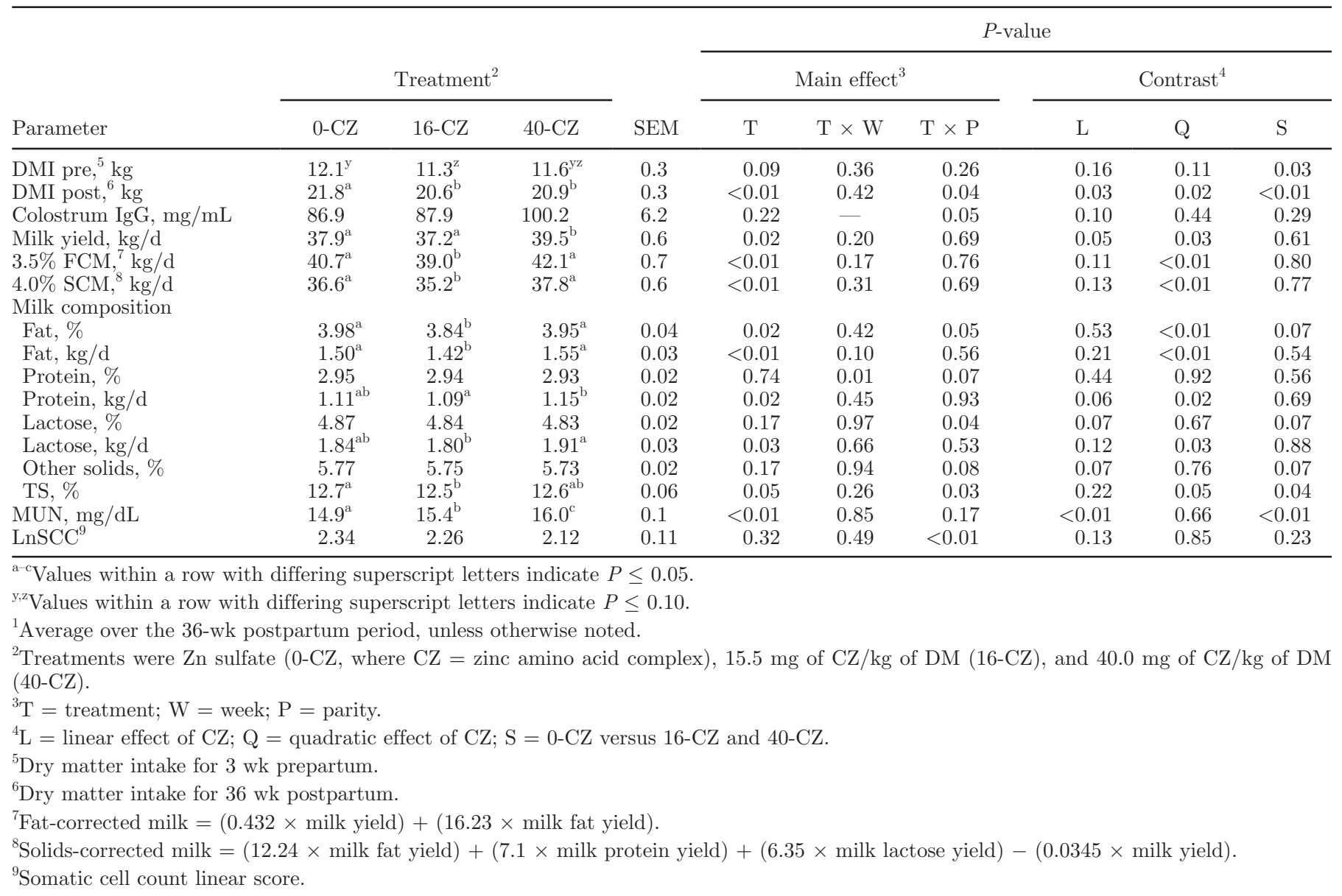




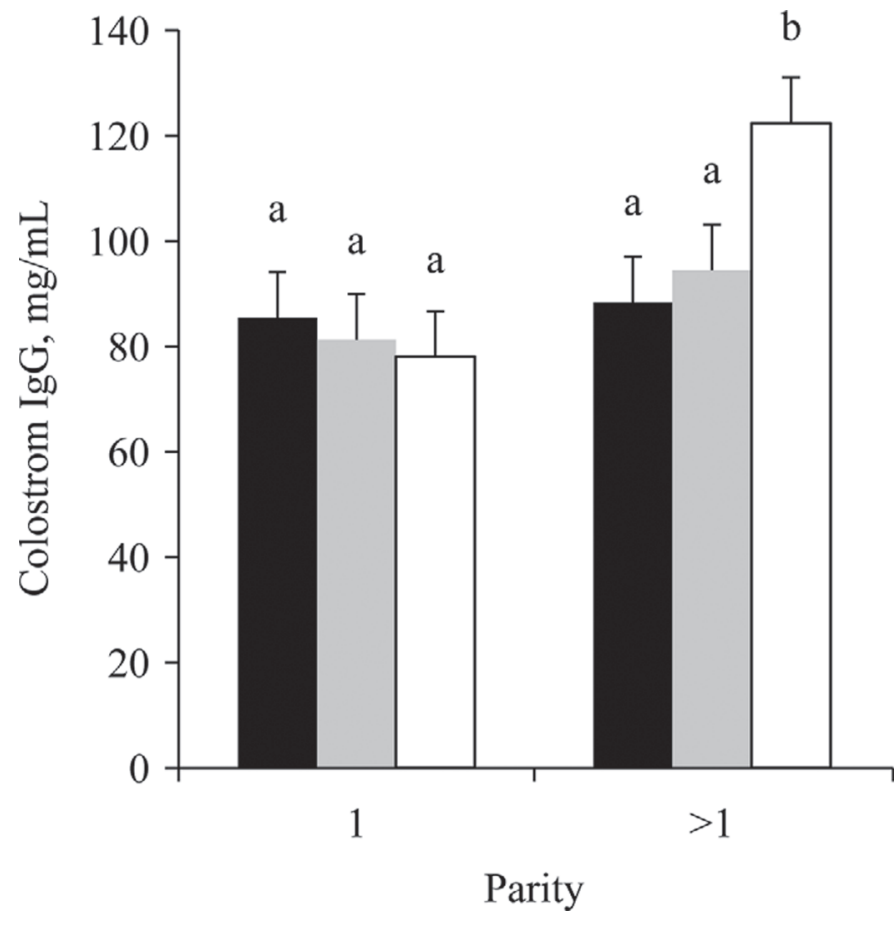

Figure 1. Effects of zinc amino acid complex (CZ) and postparturition parity on IgG concentration in colostrum of cows fed a diet with $75 \mathrm{mg}$ of supplemental zinc/ $\mathrm{kg}$ of DM, provided entirely as zinc sulfate (0-CZ; black bars); the 0-CZ diet, except with $33.3 \mathrm{mg}$ of zinc sulfate/ $\mathrm{kg}$ of DM in the prepartum and $15.5 \mathrm{mg}$ of zinc sulfate $/ \mathrm{kg}$ of DM in the postpartum diet being replaced by CZ from Availa-Zn (Zinpro Corp., Eden Prairie, MN; 16-CZ; gray bars); and the 0-CZ diet, except with $66.6 \mathrm{mg}$ of zinc sulfate $/ \mathrm{kg}$ of DM in the prepartum and $40.0 \mathrm{mg}$ of zinc sulfate $/ \mathrm{kg}$ of $\mathrm{DM}$ in the postpartum diet being replaced by Availa-Zn (40-CZ; white bars). Means within parity with different letters $(\mathrm{a}$ and $\mathrm{b})$ differ $(P<0.05 ; \mathrm{SEM}=8.64)$.

treatment by parity interaction $(P=0.05)$ was detected, as multiparous cows fed 40-CZ had increased (34\%) colostrum IgG concentration compared with multiparous cows fed $0-\mathrm{CZ}$ and $16-\mathrm{CZ}$, but no treatment effect in primiparous animals was detected (Figure 1). Feeding 40-CZ increased MY (Table 5; $P<0.05$ ) compared with 0 - and 16-CZ. The yield of $3.5 \% \mathrm{FCM}$ and $4.0 \%$ SCM decreased in cows fed 16-CZ (quadratic effect: $P$ $<0.01$; Table 5 ).

Milk fat content $(P<0.05)$ and yield $(P<0.01)$ decreased in cows fed 16-CZ compared with those fed $0-\mathrm{CZ}$ and $40-\mathrm{CZ}$ (3.84 vs. $3.97 \%$ and 1.42 vs. $1.53 \mathrm{~kg} / \mathrm{d}$, respectively; Table 5$)$ with a quadratic effect $(P<0.01)$ observed for both parameters. Effects of treatment on milk fat content are primarily explained by a treatment by parity interaction $(P<0.05)$, as milk fat decreased in multiparous cows fed 16-CZ compared with those fed $0-\mathrm{CZ}$ and $40-\mathrm{CZ}$, but no treatment effects were detected in first-parity animals. Cows fed CZ tended $(P=0.07)$ to have reduced milk fat content (Table 5$)$ but this is largely due to the effects of reduced milk fat content in 16-CZ-fed cows.
No treatment effects on milk protein content were detected, but a treatment by week interaction $(P<$ 0.01 ) indicated that 40-CZ-fed cows had decreased milk protein concentration compared with cows fed $0-\mathrm{CZ}$ and $16-\mathrm{CZ}$ at wk 1 . Relative to both $0-$ and $16-\mathrm{CZ}$, a tendency $(P=0.07)$ existed for a treatment by parity interaction for milk protein content, as primiparous cows fed 40-CZ tended to have lower milk protein levels, whereas multiparous cows fed 40-CZ tended to have higher milk protein content. Feeding 40-CZ increased milk protein yield $(5.2 \% ; P<0.05)$ relative to cows fed 0 - and $16-\mathrm{CZ}$. Feeding CZ tended $(P=0.07)$ to linearly decrease milk lactose content and this was partially explained by the treatment by parity interaction $(P$ $<0.05$ ), where no treatment difference was detected in primiparous animals but milk lactose decreased in multiparous cows compared with cows fed 0-CZ. A quadratic effect $(P<0.05)$ of treatment on milk lactose yield was detected, as feeding $16-\mathrm{CZ}$ reduced lactose yields $(0.11 \mathrm{~kg} / \mathrm{d})$ compared with feeding 40-CZ.

Increasing the level of CZ resulted in a linear increase $(P<0.01)$ in MUN content (Table 5). Relative to cows fed $0-\mathrm{CZ}$, feeding $\mathrm{CZ}$ resulted in a $5.4 \%$ increase (source effect: $P<0.01$ ) in MUN. No overall effect on milk linear SCC (LnSCC) was detected, but a treatment by parity interaction $(P<0.01)$ for LnSCC was detected, as multiparous cows fed increasing amounts of $\mathrm{CZ}$ had decreased LnSCC, but the LnSCC was unaffected in primiparous cows (Figure 2).

Feed efficiency increased with increased CZ (linear effect: $P<0.01)$ and this is primarily explained by the increase $(P<0.01)$ in cows fed 40-CZ compared with 0 -CZ (Table 6; $\mathrm{MY} / \mathrm{DMI}=9.3 \%$; FCM $/ \mathrm{DMI}=8.7 \%$; $\mathrm{SCM} / \mathrm{DMI}=8.0 \%)$. Cows from both $\mathrm{CZ}$ treatments had increased (source effect: $P<0.01$ ) feed efficiency compared with cows fed $0-\mathrm{CZ}$, regardless of the numerator used to calculate feed efficiency $(\mathrm{MY} / \mathrm{DMI}=$ $6.7 \% ; \mathrm{FCM} / \mathrm{DMI}=5.6 \% ; \mathrm{SCM} / \mathrm{DMI}=5.1 \%$; Table 6 ).

No treatment differences were detected in calf birth weight, BW at wk 36, or BCS (Table 6). A treatment by week interaction for BW was detected, largely explained by the fact that multiparous cows fed CZ were heavier (source effect: $P<0.01$ ) at calving compared with those fed 0 -CZ (Table 6 ). A treatment by parity interaction $(P<0.05)$ in BW loss from calving to wk 4 of lactation was detected, as primiparous cows fed 40-CZ lost more BW than those fed $0-\mathrm{CZ}$ and $16-\mathrm{CZ}$, but no treatment effect on BW loss was detected in multiparous cows.

Effects of treatments on plasma metabolites and rectal temperature are shown in Table 7 . No treatment effects were detected for rectal temperature, DIM at maximum rectal temperature, plasma BHBA, or maximum plasma BHBA concentration. A tendency existed 


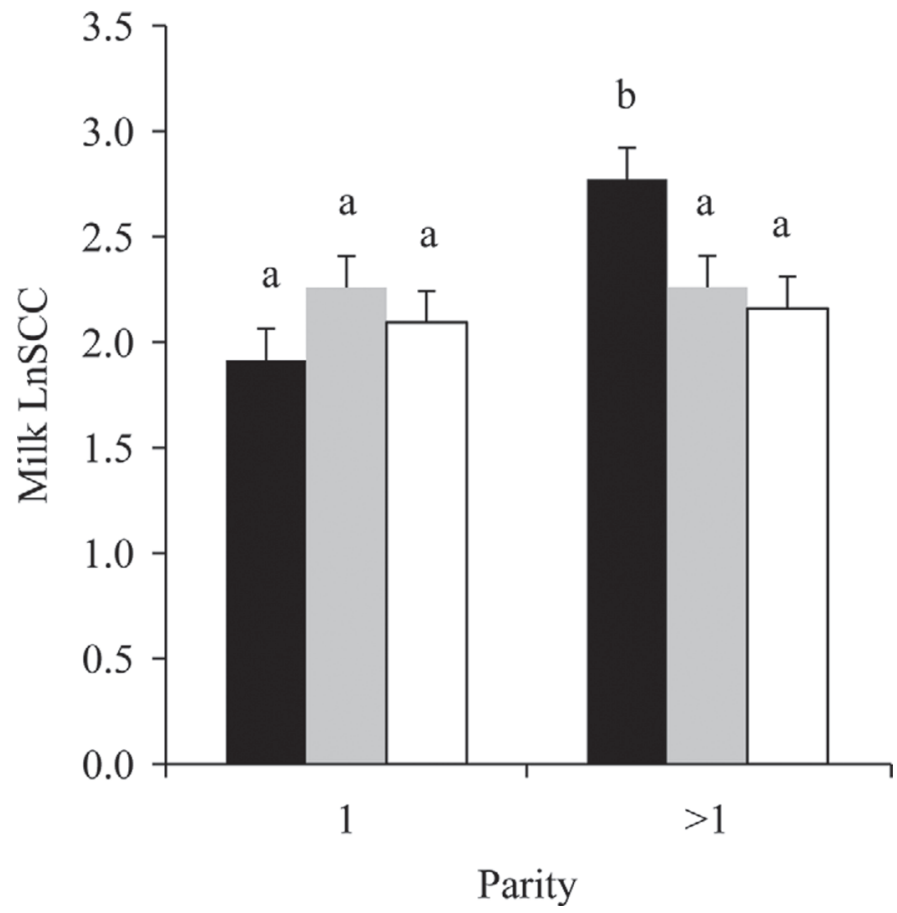

Figure 2. Effects of zinc amino acid complex (CZ) and postparturition parity on milk linear SCC (LnSCC) of cows fed a diet with $75 \mathrm{mg}$ of supplemental zinc $/ \mathrm{kg}$ of DM, provided entirely as zinc sulfate (0CZ; black bars); the 0-CZ diet, except with $33.3 \mathrm{mg}$ of zinc sulfate $/ \mathrm{kg}$ of DM in the prepartum and $15.5 \mathrm{mg}$ of zinc sulfate $/ \mathrm{kg}$ of DM in the postpartum diet being replaced by $\mathrm{CZ}$ from Availa-Zn (Zinpro Corp., Eden Prairie, MN; 16-CZ; gray bars); and the 0-CZ diet, except with $66.6 \mathrm{mg}$ of zinc sulfate $/ \mathrm{kg}$ of DM in the prepartum and $40.0 \mathrm{mg}$ of zinc sulfate $/ \mathrm{kg}$ of DM in the postpartum diet being replaced by Availa-Zn (40-CZ; white bars). Means within parity with different letters (a and b) differ $(P<0.05$; SEM $=0.152)$.

for maximum rectal temperature to increase with increasing CZ level (linear effect: $P=0.07$ ). A quadratic effect of $\mathrm{CZ}(P<0.05)$ on plasma glucose concentrations was detected, as plasma glucose concentration was numerically and statistically increased in $16-\mathrm{CZ}$ compared with 0-CZ- and 40-CZ-fed cows, respectively.

Increasing dietary $\mathrm{CZ}$ resulted in a linear increase $(P=0.05)$ in plasma NEFA levels. Plasma NEFA concentration was greater in cows fed $\mathrm{CZ}$, regardless of amount of $\mathrm{CZ}$ fed (source effect: $P<0.01$ ). The main effect of treatment on plasma NEFA concentration is partially explained by the treatment by parity interaction $(P<0.05)$, as primiparous cows fed CZ had increased $(22.6 \%)$ NEFA concentration compared with primiparous cows fed $0-\mathrm{CZ}$, whereas no effect of treatments on plasma NEFA concentration was detected in multiparous cows. Maximum NEFA concentration was greater in animals fed $\mathrm{CZ}$ compared with cows fed $0-\mathrm{CZ}$ (872 vs. $744 \mu \mathrm{Eq} / \mathrm{L}$; source effect: $P<0.05$ ). The maximum level of NEFA in plasma was detected earlier in cows fed 40-CZ compared with cows fed 16-CZ (5 vs. 12 DIM; $P<0.05)$. The maximum plasma BHBA concen- tration in cows fed $40-\mathrm{CZ}$ was numerically detected $(P$ $<0.13) 8$ d earlier relative to cows fed $0-\mathrm{CZ}$, resulting in a linear effect $(P<0.05)$ of CZ. Regardless of level of supplementation, feeding CZ tended to decrease DIM at maximum BHBA concentration (source effect: $P=$ 0.06; Table 7).

Treatment effects on reproductive parameters are shown in Table 8. No treatment differences were detected for DIM at first service or the percentage pregnant by 150 DIM. However, primiparous cows fed 40-CZ had a 7-d increase in DIM at first service compared with those fed $0-\mathrm{CZ}$, whereas no treatment effect was detected for multiparous cows (treatment by parity interaction: $P=0.07$; Table 8 ). Increasing $\mathrm{CZ}$ supplementation resulted in both linear $(P=0.10)$ and quadratic $(P<0.01)$ responses in services per conception (Table 8). Regardless of supplemented level, CZ decreased services per conception (source effect: $P<$ 0.01; Table 8).

\section{DISCUSSION}

The biological functions of zinc continue to be elucidated and, thus, the appreciation for how zinc and zinc source could influence lactation performance continues to evolve. The NRC increased the recommended dietary zinc levels for lactating dairy cows in its last publication (NRC, 2001); however, trace mineral recommendations may be inadequate for genetically superior animals. For example, supplementing trace minerals above NRC recommendations results in improved lactational performance and, in some cases, minerals supplemented at NRC levels caused mineral deficiencies (Kincaid et al., 2003; Weiss and Socha, 2005). Despite the lack of understanding by which a more bioavailable form of zinc mechanistically improves productivity, some explanations could be improved mammary and claw health, enhanced immune function during the transition period, and possibly improved integrity of the gastrointestinal tract. Our hypothesis was that increasing the ratio of $\mathrm{CZ}$ to zinc sulfate during both the prepartum and postpartum period would increase production or production efficiency, or both, throughout lactation. An increase in overall health and epithelial tissue integrity could reduce the energy required to maintain these systems and theoretically result in more available energy, thus improving production parameters. Moreover, little is known about the effects supplemental zinc has on bioenergetic parameters in blood (i.e., NEFA, BHBA, and glucose concentrations, among others), which is of interest in determining zinc's role in nutrient metabolism of dairy cows.

In general, trace mineral research in livestock production is limited and quite variable. One explanation 
Table 6. Effect of treatment on feed efficiency, BW, and BCS

\begin{tabular}{|c|c|c|c|c|c|c|c|c|c|c|}
\hline Parameter & \multicolumn{3}{|c|}{ Treatment $^{2}$} & SEM & \multicolumn{6}{|c|}{$P$-value } \\
\hline \multicolumn{11}{|l|}{ Feed efficiency ${ }^{5}$} \\
\hline MY/DMI & $1.82^{\mathrm{a}}$ & $1.89^{\mathrm{a}}$ & $1.99^{\mathrm{b}}$ & 0.04 & $<0.01$ & 0.57 & 0.35 & $<0.01$ & 0.71 & $<0.01$ \\
\hline $\mathrm{FCM} / \mathrm{DMI}$ & $1.95^{\mathrm{a}}$ & $2.00^{\mathrm{a}}$ & $2.12^{\mathrm{b}}$ & 0.03 & $<0.01$ & 0.25 & 0.21 & $<0.01$ & 0.33 & $<0.01$ \\
\hline $\mathrm{BW},{ }^{6} \mathrm{~kg}$ & 612 & 612 & 611 & 4 & 0.96 & $<0.01$ & 0.64 & 0.78 & 0.98 & 0.78 \\
\hline $\mathrm{BW} 09^{7} \mathrm{~kg}$ & $641^{\mathrm{a}}$ & $658^{\mathrm{b}}$ & $670^{\mathrm{b}}$ & 7 & $<0.01$ & - & 0.02 & $<0.01$ & 0.73 & $<0.01$ \\
\hline $\mathrm{BW} \Delta,{ }^{8} \mathrm{~kg}$ & $-60^{\mathrm{a}}$ & $-74^{\mathrm{b}}$ & $-87^{\mathrm{b}}$ & 7 & $<0.01$ & - & 0.02 & $<0.01$ & 0.89 & $<0.01$ \\
\hline BW $36,{ }^{9} \mathrm{~kg}$ & 658 & 663 & 658 & 9 & 0.88 & & 0.49 & 0.98 & 0.62 & 0.81 \\
\hline $\mathrm{BCS}^{10}$ & 2.9 & 2.9 & 3.0 & 0.1 & 0.42 & - & 0.16 & - & - & - \\
\hline
\end{tabular}

${ }_{\mathrm{a}, \mathrm{b}}$ Values within a row with differing superscript letters indicate $P<0.05$.

${ }^{1}$ Average over the 36 -wk postpartum period, unless otherwise noted.

${ }^{2}$ Treatments were Zn sulfate (0-CZ, where $\mathrm{CZ}=$ zinc amino acid complex), $15.5 \mathrm{mg}$ of $\mathrm{CZ} / \mathrm{kg}$ of DM (16-CZ), and $40.0 \mathrm{mg}$ of $\mathrm{CZ} / \mathrm{kg}$ of $\mathrm{DM}$ (40-CZ).

${ }^{3} \mathrm{~T}=$ treatment; $\mathrm{W}=$ week; $\mathrm{P}=$ parity.

${ }^{4} \mathrm{~L}=$ linear effect of $\mathrm{CZ} ; \mathrm{Q}=$ quadratic effect of $\mathrm{CZ} ; \mathrm{S}=0-\mathrm{CZ}$ versus $16-\mathrm{CZ}$ and $40-\mathrm{CZ}$.

${ }^{5} \mathrm{MY}=$ milk yield.

${ }^{6}$ Overall BW.

${ }^{7}$ Body weight at calving.

${ }^{8}$ Body weight change from calving to wk 4 of lactation.

${ }^{9}$ Body weight at wk 36 of lactation.

${ }^{10}$ Body condition scored as recommended by Wildman et al. (1982).

is the fact that extensive variation exists within the literature regarding the source and level of supplementation, length of the treatment period, stage of production, species, sources of other trace minerals, and trace mineral concentration in dietary ingredients or water. All of these experimental inconsistencies make it difficult to accurately compare our results with other trials. The current trial is unique in that the dietary treatment was 3 different ratios of CZ to zinc sulfate, as all diets were formulated to supply a similar amount of added zinc while simultaneously keeping the source and level of other supplemental trace minerals constant.

Table 7. Effect of treatments on rectal temperature $(\mathrm{Tr})$ and plasma metabolites

\begin{tabular}{|c|c|c|c|c|c|c|c|c|c|c|}
\hline \multirow{2}{*}{ Parameter } & & & & \multirow{2}{*}{ SEM } & \multicolumn{6}{|c|}{$P$-value } \\
\hline & \multicolumn{3}{|c|}{ Treatment $^{1}$} & & \multicolumn{3}{|c|}{ Main effect ${ }^{2}$} & \multicolumn{3}{|c|}{ Contrast $^{3}$} \\
\hline $\mathrm{Tr},{ }^{\circ} \mathrm{C}$ & 38.36 & 38.34 & 38.39 & 0.03 & 0.47 & 0.14 & 0.59 & 0.42 & 0.33 & 0.82 \\
\hline Maximum $\mathrm{Tr},{ }^{\circ} \mathrm{C}$ & 38.94 & 38.95 & 39.13 & 0.08 & 0.14 & - & 0.57 & 0.07 & 0.37 & 0.25 \\
\hline DIM at maximum $\mathrm{Tr}, \mathrm{d}$ & 12 & 16 & 12 & 3 & 0.48 & - & 0.78 & 1.00 & 0.23 & 0.53 \\
\hline Maximum NEFA concentration, $\mu \mathrm{Eq} / \mathrm{L}$ & 742 & 899 & 834 & 60 & 0.12 & - & 0.29 & 0.24 & 0.11 & 0.05 \\
\hline DIM at maximum NEFA concentration, d & $7^{\mathrm{ab}}$ & $12^{\mathrm{a}}$ & $5^{\mathrm{b}}$ & 3 & 0.05 & - & 0.39 & 0.50 & $<0.05$ & 0.47 \\
\hline $\mathrm{BHBA}, \mathrm{mg} / \mathrm{dL}$ & 7.6 & 7.8 & 8.3 & 0.4 & 0.26 & 0.10 & 0.25 & 0.11 & 0.68 & 0.21 \\
\hline Maximum BHBA concentration, mg/dL & 13.6 & 14.1 & 15.6 & 1.5 & 0.58 & - & 0.44 & 0.31 & 0.79 & 0.42 \\
\hline DIM at maximum BHBA concentration, $\mathrm{d}$ & 22 & 17 & 14 & 3 & 0.13 & - & 0.17 & $<0.05$ & 0.76 & 0.06 \\
\hline
\end{tabular}


Table 8. Effect of treatments on reproductive performance

\begin{tabular}{|c|c|c|c|c|c|c|c|c|c|}
\hline Parameter & & & & SEM & \multicolumn{5}{|c|}{$P$-value } \\
\hline DIM at first service & 60 & 61 & 63 & 2 & 0.41 & 0.07 & 0.18 & 0.94 & 0.27 \\
\hline DIM at conception & 114 & 93 & 108 & 9 & 0.16 & 0.25 & 0.63 & 0.07 & 0.18 \\
\hline Services/conception & $3.1^{\mathrm{a}}$ & $2.0^{\mathrm{b}}$ & $2.6^{\mathrm{ab}}$ & 0.3 & $<0.01$ & 0.46 & 0.10 & $<0.01$ & $<0.01$ \\
\hline
\end{tabular}

In the current study, CZ decreased DMI during both the prepartum and postpartum periods. One possible explanation for this might be the fact that zinc sulfate decreased with increasing $\mathrm{CZ}$ supplementation. Reagent-grade zinc sulfate has been shown to decrease cellulose digestion in vitro (Sala, 1957). Effects of treatments on rumen fermentation were not measured in the current study. However, based on the hepatic oxidation theory as proposed by Allen et al. (2009), it is possible that increasing the ratio of $\mathrm{CZ}$ to zinc sulfate improved hepatic oxidative fuel supply and subsequently decreased feed intake. Effects of CZ on DMI were not reported in the trials summarized by Kellogg et al. (2004) because cows in those experiments were group fed. Feed intake has not been affected by amino acid complexes of zinc, manganese, copper, and cobalt glucoheptonate in studies where individual DMI were measured (Hackbart et al., 2010) or in group feeding studies (Ballantine et al., 2002; Nocek et al., 2006; DeFrain et al., 2009). It is important to note that differences in breed, stage of production, source and level of trace minerals, and duration of treatments between our trial and others make it difficult to directly compare results. The relationship between zinc status and appetite regulation remains under investigation, especially in rodents and humans. Mantzoros et al. (1998) studied the effect of zinc supplementation in zinc-depleted human subjects and suggested that zinc may influence serum leptin levels via the control of cytokines, namely IL-2 and tumor necrosis factor $\alpha$. Although circulating leptin was not measured in the study under discussion, it is possible that feeding CZ may have affected leptin and contributed to the decrease in DMI.

Zinc has biological roles characterized by catalytic, structural, and regulatory functions (Dibley, 2001) and, therefore, is a critical component of protein synthesis. Although feeding $\mathrm{CZ}$ decreased prepartum intake and therefore total zinc intake, colostral IgG content of mul- tiparous cows was increased (34\%) in cows fed $40-\mathrm{CZ}$ relative to those fed $0-\mathrm{CZ}$ and $16-\mathrm{CZ}$. Increased colostral IgG concentration has previously been reported in cows fed $\mathrm{Zn}, \mathrm{Mn}, \mathrm{Cu}$, and Co complexes (Kincaid and Socha, 2004; Kinal et al., 2005) and colostrum IgG content increases with advancing parity (Morrill et al., 2012). The response observed in multiparous cows fed 40-CZ suggests that zinc plays an important role in the synthesis of colostrum IgG and supplementing cows with a more bioavailable form of zinc may provide for improved passive immunoglobulin transfer in newborn calves.

Milk yield increased in cows fed 40-CZ compared with cows fed $0-\mathrm{CZ}$ and $16-\mathrm{CZ}$, whereas feeding $16-\mathrm{CZ}$ decreased $3.5 \% \mathrm{FCM}$ and $4.0 \% \mathrm{SCM}$ yields. The decrease in milk fat and SCM observed in the 16-CZ group is difficult to explain, as feeding amino acid complexes of zinc, copper and manganese, and cobalt glucoheptonate did not reduce milk fat in other trials (Kincaid and Socha, 2004). Pregnancy is known to negatively affect milk yield (Bachman et al., 1988), which may have contributed to the reduced milk yield in cows fed 16-CZ, considering the fact cows fed 16-CZ had the lowest services per conception and subsequently conceived roughly 1 cycle earlier than cows fed $0-\mathrm{CZ}$ and 40-CZ. Others have found increased milk production in cows fed a portion of the trace minerals as cobalt glucoheptonate and zinc, copper, and manganese amino acid complexes (Ballantine et al., 2002; Nocek et al., 2006; Siciliano-Jones et al., 2008). In a 12-trial summary, Kellogg et al. (2004) reported an increase in MY, FCM, and SCM in cows supplemented with CZ compared with those fed inorganic zinc. Some trials have reported no effect of trace mineral source (amino acid complexes of zinc, copper, and manganese, and cobalt glucoheptonate vs. inorganics) on milk fat, protein, or lactose yield (Siciliano-Jones et al., 2008; DeFrain et al., 2009; Hackbart et al., 2010), which agrees with our results 
(besides cows fed 16-CZ). In contrast, other studies have reported increases in milk fat and protein yield in cows fed diets containing zinc, copper, manganese, and cobalt complexes (Ballantine et al., 2002; Kellogg et al., 2004; Nocek et al., 2006).

One explanation for the increase in milk and milk components in cows fed trace mineral complexes is improved udder health. Increasing the level of CZ supplementation resulted in a linear decrease in LnSCC in multiparous cows. Diets containing zinc, copper, and manganese amino acid complexes and cobalt glucoheptonate have decreased milk SCC in other studies (Kel$\operatorname{logg}$ et al., 2004; Nocek et al., 2006; Siciliano-Jones et al., 2008; DeFrain et al., 2009). Rationalization for improved mammary health is based on the fact that zinc is required for the maintenance of epithelial integrity, stabilization of cell membranes, and activation of the immune system (Miller and Madsen, 1992). Furthermore, older cows are less resistant to the onset of IMI in early lactation (Oliver and Mitchell, 1983). Therefore, the decrease in milk LnSCC in multiparous cows may partially be explained by the role of $\mathrm{CZ}$ in forming the teat canal keratin plug, as noted by Spain (1993). Taken together, increased zinc availability and retention could potentially improve immune system function or improve teat and mammary epithelial health, or both.

Due to the requirement of zinc for milk synthesis (4 $\mathrm{mg} / \mathrm{kg}$ of milk; NRC, 2001), the greatest demand for zinc coincides with peak milk production. Therefore, providing a more bioavailable zinc source may allow for increased milk production efficiency. Feed efficiency increased in cows fed 40-CZ but not from animals fed 16-CZ. Total zinc intake less CZ was 2,050 and 1,714 $\mathrm{mg} / \mathrm{d}$ for $16-\mathrm{CZ}$ and $40-\mathrm{CZ}$ treatments, respectively. It is possible that decreasing the amount of zinc sulfate in the rumen increased cellulose digestion, as reported by Sala (1957), and led to increases in feed efficiency. Few papers have reported feed efficiency in dairy cows supplemented with increasing amounts of CZ. Smith et al. (1999) reported a 6.5\% improvement in ECM yield (3.5\% fat and $3.0 \%$ true protein) per kilogram of DMI in cows supplemented with $360 \mathrm{mg}$ of $\mathrm{Zn}$ from $\mathrm{CZ}$ in diets containing over $170 \mathrm{mg}$ of $\mathrm{Zn} / \mathrm{kg}$. Cows fed $40-\mathrm{CZ}$ were consuming $836 \mathrm{mg}$ of $\mathrm{Zn} / \mathrm{d}$ as $\mathrm{CZ}$ and had a $9 \%$ improvement in FCM/DMI over cows fed $0-\mathrm{CZ}$ in diets containing 115 to $120 \mathrm{mg}$ of total zinc $/ \mathrm{kg}$. Saenmahayak et al. (2010) used a similar dietary treatment application as the current study (replacing a portion of supplemental zinc sulfate with CZ) and also reported improvements in feed conversion efficiency in broiler chickens fed diets containing $40 \mathrm{mg}$ of zinc amino acid complex/kg (Saenmahayak et al., 2010).

Although directly comparing results from animals at different physiological states should be conducted with care, it is important to note that $\mathrm{CZ}$ may improve conversion of dietary nutrients into valued products (muscle or milk). The change in BW is the primary line of evidence that agrees with the feed efficiency data. Both 16-CZ- and 40-CZ-fed cows lost $19 \mathrm{~kg}$ more BW than 0-CZ-fed cows within the first $4 \mathrm{wk}$ of lactation and this suggests that CZ-fed cows prioritized milk synthesis over either accretion of or maintenance of body tissue (likely adipose tissue). However, overall BW (average between wk 1 and 36 of lactation) did not differ among treatments and this suggests that cows fed $\mathrm{CZ}$ were able to efficiently replenish body reserves during later stages of lactation. Our results for BW parameters are similar to observations by Hackbart et al. (2010), who indicated no effect of treatment but increased $\mathrm{BW}$ loss in the first month of lactation in cows supplemented with CZ in addition to cobalt glucoheptonate and amino acid complexes of copper and manganese relative to those fed only sulfate $(\mathrm{Zn}, \mathrm{Cu}$, and $\mathrm{Mn}$ ) and carbonate (Co) sources.

Plasma NEFA, BHBA, and glucose concentrations and rectal temperature were measured to determine if CZ had effects on tissue catabolism or metabolism, or both. Although the temporal pattern for BHBA and glucose concentration and rectal temperature followed the expected trend, no treatment differences were detected for these variables. However, feeding CZ increased plasma NEFA concentration and the elevated plasma NEFA concentration also corroborates the increased feed efficiency and correlates well with the increased BW loss in the 16-CZ- and 40-CZ-fed cows. Another trial previously measured plasma NEFA levels in cows fed amino acid complexes of zinc, copper, and manganese and cobalt glucoheptonate compared with trace minerals provided as sulfates, and reported no difference (Kincaid and Socha, 2004). We suspect that the effect of increasing CZ on NEFA levels is an indirect consequence of reduced DMI and not a direct postabsorptive effect of zinc on adipose tissue mobilization. Although treatment effects were detected among NEFA and BHBA concentrations, the biological significance is questionable, considering all treatment means for NEFA and BHBA concentrations were below the thresholds outlined by Duffield and LeBlanc (2009).

The importance of zinc in cell proliferation becomes especially apparent when it comes to high-proliferating tissues (e.g., skin/hair, intestinal epithelia, and the reproductive tract). Zinc deficiencies can lead to reduced ovulation, poor oocyte quality, abortion, fetal malformations, lower birth weights, and offspring with reduced or defective immune function (Hurley and Shrader, 1975; Record et al., 1985; Apgar, 1992). This is of great concern and interest to the dairy industry because of lower reproduction rates compared with 
other livestock species and the economic consequence of poor fecundity. In theory, supplying a more bioavailable form of zinc should provide benefits to reproductive indices in high-producing dairy cows.

Although our experimental design and the number of animals enrolled in the study may be insufficient to draw firm conclusions on reproductive performance, we were able to statistically detect an improvement in services per conception in CZ-fed cows compared with 0-CZ-fed cows. No other treatment differences were detected in other reproductive indices but $\mathrm{CZ}$ resulted in numerical decreases in DIM at conception, days open, and increased percentage of cows pregnant at 150 DIM. Ballantine et al. (2002) reported a decrease in days open and a tendency for an increase in cows pregnant at 150 DIM and first-service conception risk in cows supplemented with $\mathrm{Zn}, \mathrm{Mn}, \mathrm{Cu}$, and Co complexes. Similarly, Nocek et al. (2006) demonstrated improvements in reproductive performance in cows fed a mixture of $\mathrm{Zn}$, $\mathrm{Cu}, \mathrm{Mn}$, and Co complexes and sulfates compared with cows receiving only trace mineral complexes or trace minerals from sulfates at the same level in the first lactation. Interestingly, Nocek et al. (2006) continued treatments into a second lactation with the same cows, where they noted that cows cycled sooner after calving, had higher first-service conception risk, and had more cows pregnant by 150 DIM. Another trial also reported a tendency for increased percentage of cows pregnant at 150 DIM in cows fed a mixture of sulfates and Zn, $\mathrm{Mn}, \mathrm{Cu}$, and $\mathrm{Co}$ complexes compared with similar levels of those minerals provided as sulfates (DeFrain et al., 2009). Whereas some trials have reported improved reproductive indices (Uchida et al., 2001; Ballantine et al., 2002; Nocek et al., 2006; DeFrain et al., 2009) similar to our results, others have concluded no effect of trace mineral source on reproduction (Siciliano-Jones et al., 2008; Hackbart et al., 2010). Although results have been somewhat variable, it is apparent that research has demonstrated a positive effect of supplementing a portion of trace minerals as amino acid complexes on reproductive performance in dairy cows.

\section{CONCLUSIONS}

Increasing the ratio of $\mathrm{CZ}$ to zinc sulfate before calving and during lactation may improve feed efficiency, in large part by decreasing DMI while maintaining milk production. In addition to improving feed efficiency, these data suggest that CZ-fed cows were able to manage body reserves more efficiently throughout lactation, as they lost more BW in early lactation but replenished body reserves during the later stages of lactation. Furthermore, replacing a portion of zinc sulfate with $\mathrm{CZ}$ resulted in increases in colostrum IgG concentration and tended to decrease LnSCC in multiparous cows. In summary, our results indicate that supplementing zinc as mixture of $\mathrm{CZ}$ and zinc sulfate, as opposed to supplementing only zinc sulfate, has beneficial effects on production parameters in dairy cows, with those benefits becoming more apparent as the ratio of $\mathrm{CZ}$ to zinc sulfate increase.

\section{REFERENCES}

Allen, M. S., B. J. Bradford, and M. Oba. 2009. Board-Invited Review: The hepatic oxidation theory of the control of feed intake and its application to ruminants. J. Anim. Sci. 87:3317-3334.

Apgar, J. 1992. Zinc and reproduction: An update. J. Nutr. Biochem. $3: 266-278$.

AOAC International. 1996. Official Methods of Analysis. 16th ed. AOAC International, Arlington, VA.

AOAC International. 2005. Official Methods of Analysis. 18th ed. AOAC International, Arlington, VA.

Bachman, K. C., M. J. Hayen, D. Morse, and C. J. Wilcox. 1988. Effect of pregnancy, milk yield, and somatic cell count on bovine milk fat hydrolysis. J. Dairy Sci. 71:925-931.

Ballantine, H. T., M. T. Socha, D. J. Tomlinson, A. B. Johnson, A. S. Fielding, J. K. Shearer, and S. R. van Amstel. 2002. Effects of feeding complexed zinc, manganese, copper and cobalt to late gestation and lactating dairy cows on claw integrity, reproduction and lactation performance. Prof. Anim. Sci. 18:211-218.

Campbell, M. H., and J. K. Miller. 1998. Effect of supplemental dietary vitamin $\mathrm{E}$ and zinc on reproductive performance of dairy cows and heifers fed excess iron. J. Dairy Sci. 81:2693-2699.

DeFrain, J. M., M. T. Socha, D. J. Tomlinson, and D. Kluth. 2009. Effect of complexed trace minerals on the performance of lactating dairy cows on a commercial dairy. Prof. Anim. Sci. 25:709-715.

Dibley, M. J. 2001. Zinc. Page 329 in Present Knowledge in Nutrition. 8th ed. B. A. Bowman and R. M. Russell, ed. Int. Life Sci. Inst. Press, Washington, DC.

Duffield, T. F., and S. J. LeBlanc. 2009. Interpretation of serum metabolic parameters around the transition period. Pages 106-114 in Proc. Southwest Nutr. Mgmt. Conf. Online. Accessed Mar. 1, 2013. http://animal.cals.arizona.edu/swnmc/Proceedings/2009/ 11Duffield_2_09.pdf.

Eaton, A. D., L. S. Clesceri, and A. E. Greenberg, editors. 1995. Standard Methods for Examination of Water and Wastewater. 19th ed. Am. Public Health Assoc., Washington, DC.

Hackbart, K. S., R. M. Ferreira, A. A. Dietsche, M. T. Socha, R. D. Shaver, M. C. Wiltbank, and P. M. Fricke. 2010. Effect of dietary organic zinc, manganese, copper, and cobalt supplementation on milk production, follicular growth, embryo quality, and tissue mineral concentrations in dairy cows. J. Anim. Sci. 88:3856-3870.

Hurley, L. S., and R. E. Shrader. 1975. Abnormal development of preimplantation rat eggs after three days of maternal dietary zinc deficiency. Nature 254:427-429.

Kellogg, D. W., D. J. Tomlinson, M. T. Socha, and A. B. Johnson. 2004. Review: Effects of zinc methionine complex on milk production and somatic cell count of dairy cows: Twelve-trial summary. Prof. Anim. Sci. 20:295-301.

Kinal, S., A. Korniewicz, D. Jamroz, R. Zieminski, and M. Slupczynska. 2005. Dietary effects of zinc, copper and manganese chelates and sulphates on dairy cows. J. Food Agric. Environ. 3:168-172.

Kincaid, R. L., L. E. Lefebvre, J. D. Cronrath, M. T. Socha, and A. B. Johnson. 2003. Effect of dietary cobalt supplementation on cobalt metabolism and performance of dairy cattle. J. Dairy Sci. 86:1405-1414.

Kincaid, R. L., and M. T. Socha. 2004. Inorganic versus complexed trace mineral supplements on performance of dairy cows. Prof. Anim. Sci. 20:66-73.

Littell, R. C., G. A. Milliken, S. W. Walter, and R. D. Wolfinger. 1996. SAS Systems for Mixed Models. SAS Institute Inc., Cary, NC. 
Mantzoros, C. S., A. S. Prasad, F. W. J. Beck, S. Grabowski, J. Kaplan, C. Adair, and G. J. Brewer. 1998. Zinc may regulate serum leptin concentrations in humans. J. Am. Coll. Nutr. 17:270-275.

Miller, J. K., and F. C. Madsen. 1992. Trace minerals. Page 297 in Large Dairy Herd Management. H. H. Van Horn and C. J. Wilcox, ed. Am. Dairy Sci. Assoc., Champaign, IL.

Morrill, K. M., E. Conrad, A. Lago, J. Campbell, J. Quigley, and H. Tyler. 2012. Nationwide evaluation of quality and composition of colostrum on dairy farms in the United States. J. Dairy Sci. 95:3997-4005.

Nocek, J. E., M. T. Socha, and D. J. Tomlinson. 2006. The effect of trace mineral fortification level and source on performance of dairy cattle. J. Dairy Sci. 89:2679-2693.

Nockels, C. F., J. DeBonis, and J. Torrent. 1993. Stress induction affects copper and zinc balance in calves fed organic and inorganic copper and zinc sources. J. Anim. Sci. 71:2539-2545.

NRC. 2001. Nutrient Requirements of Dairy Cattle. 7th rev. ed. Natl Acad. Press, Washington, DC.

Oliver, S. P., and B. A. Mitchell. 1983. Susceptibility of bovine mammary gland to infections during the dry period. J. Dairy Sci 66:1162-1166.

Paripatananont, T., and R. T. Lovell. 1995. Chelated zinc reduces the dietary zinc requirement of channel catfish, Ictalurus punctatus. Aquaculture 133:73-82.

Record, I. R., I. E. Dreosti, and R. S. Tulsi. 1985. In vitro development of zinc-deficient and replete rat embryos. Aust. J. Exp. Biol. Med. Sci. 63:65-71.

Saenmahayak, B., S. F. Bilgili, J. B. Hess, and M. Singh. 2010. Live and processing performance of broiler chickens fed diets supplemented with complexed zinc. J. Appl. Poult. Res. 19:334-340.

Sala, J. C. 1957. The effect of minerals on cellulose digestion as studied in the artificial rumen. PhD Diss. University of Florida, Gainesville.

SAS Institute. 2005. SAS User's Guide: Version 9.2. SAS Institute Inc., Cary, NC.
Siciliano-Jones, J. L., M. T. Socha, D. J. Tomlinson, and J. M. DeFrain. 2008. Effect of trace mineral source on lactation performance, claw integrity, and fertility of dairy cattle. J. Dairy Sci. 91:1985-1995.

Smith, M. B., H. E. Amos, and M. A. Froetschel. 1999. Influence of ruminally undegraded protein and zinc methionine on milk production, hoof growth and composition, and selected plasma metabolites of high producing dairy cows. Prof. Anim. Sci. 15:268-277.

Spain, J. 1993. Tissue integrity: A key defense against mastitis infection: The role of zinc proteinates and a theory for mode of action. Pages 53-60 in Proc. 10th Ann. Symposium on Biotechnology in the Feed Industry. T. P. Lyons, ed. Nottingham University Press, Alltech Technical Publications, Nicholasville, KY.

Spears, J. W. 1989. Zinc methionine for ruminants: Relative bioavailability of zinc in lambs and effects on growth and performance of growing heifers. J. Anim. Sci. 67:835-843.

Tyrrell, H. F., and J. T. Reid. 1965. Prediction of the energy value of cow's milk. J. Dairy Sci. 48:1215-1223.

Uchida, K., P. Mandebvu, C. S. Ballard, C. J. Sniffen, and M. P. Carter. 2001. Effect of feeding a combination of zinc, manganese and copper amino acid complexes, and cobalt glucoheptonate on performance of early lactation high producing dairy cows. Anim. Feed Sci. Technol. 93:193-203.

Wedekind, K. J., A. E. Horton, and D. H. Baker. 1992. Methodology for assessing zinc bioavailability: Efficacy estimates for zinc-methionine, zinc sulfate, and zinc oxide. J. Anim. Sci. 70:178-187.

Weiss, W. P., and M. T. Socha. 2005. Dietary manganese for dry and lactating Holstein cows. J. Dairy Sci. 88:2517-2523.

Wildman, E. E., G. M. Jones, P. E. Wagner, R. L. Bowman, H. F. Troutt Jr., and T. N. Lesch. 1982. A dairy cow body condition scoring system and relationship to selected production characteristics. J. Dairy Sci. 65:495-501. 